\title{
Pemanfaatan Tepung Daun Eceng Gondok (Eichhornia crassipes) Difermentasi Menggunakan Cairan Rumen Sapi Terhadap Pertumbuhan Ikan Baung (Hemibagrus nemurus)
}

\author{
Utilization of Eichhornia crassipes Leaf Fermented Using Cow Rumen Fluid on the \\ Growth of Asian Redtail Fish (Hemibagrus mumurus) \\ Rahmat Kurniawan $^{1 *}$, Indra Suharman ${ }^{1}$, Adelina ${ }^{1}$ \\ ${ }^{1}$ Jurusan Budidaya Perairan, Fakultas Perikanan dan Kelautan, Universitas Riau \\ Kampus Bina Widya Jl. HR. Soebrantas Km 12.5, Pekanbaru, 28293 \\ email: rahmat.kurniawan@student.unri.ac.id
}

(Received: 08 Januari 2022; Accepted: 28 Februari 2022)

\begin{abstract}
ABSTRAK
Eceng gondok mempunyai kandungan protein serta kandungan serat kasar yang cukup tinggi sehingga perlu dilakukan pengolahan sebelum digunakan sebagai bahan pakan. Penelitian ini bertujuan untuk mengetahui pengaruh penggunaan tepung daun eceng gondok terfermentasi terhadap pertumbuhan benih ikan baung. Penelitian ini dilaksanakan pada September-November 2019 yang bertempat di BBI, Sei Tibun, Kabupaten Kampar, Riau. Ikan uji yang digunakan dalam penelitian ini adalah benih ikan baung yang berukuran $5 \mathrm{~cm}$ dengan rata-rata bobot awal 1,26 $\pm 1,17$ g sebanyak 400 ekor. Benih ini diperoleh di Desa Lipat Kain Kampar, Riau. Penelitian ini menggunakan metode Rancangan Acak Lengkap satu faktor dengan 5 taraf perlakuan dan 3 kali ulangan. Perlakuan adalah pemberian pakan persentase subsitusi tepung kedelai dengan tepung daun eceng gondok terfermentasi yang berbeda yaitu (100:0\%), (90:10\%), (80:20\%), (70:30\%), dan (60:40\%). Wadah yang digunakan pada penelitian ini adalah keramba yang berukuran $1 \times 1 \times 1 \mathrm{~m}^{3}$ sebanyak 15 unit, dengan padat tebar sebanyak 20 ekor/wadah. Hasil penelitian menunjukkan bahwa penggunaan tepung daun eceng gondok terfermentasi sebagai bahan pakan ikan baung mampu mengurangi penggunaan tepung kedelai, ini terlihat dari pertambahan bobot rata-rata benih ikan baung setiap periodenya. Penggunaan tepung daun eceng gondok terfermentasi dalam pakan sebanyak 30\% menghasilkan pertumbuhan benih ikan baung terbaik yang menghasilkan efisiensi pakan $46,64 \%$, retensi protein $18,73 \%$, laju pertumbuhan spesifik 3,85\% dan kelulushidupan 99$100 \%$.
\end{abstract}

Kata Kunci: Eceng Gondok, Rumen Sapi, Hemibagrus nemurus

\begin{abstract}
Eichhornia crassipes leaf has a protein content and high crude fiber content, so it needs to be processed before being used as feed ingredients. This study aims to determine the effect of using fermented water hyacinth leaf flour on the growth of asian redtail catfish fry. This research was conducted in September-November 2019 at BBI, Sei Tibun, Kampar Regency, Riau. The test fish used in this study were asian redtail catfish measuring $5 \mathrm{~cm}$ with an average initial weight of $1.26 \pm$ $1.17 \mathrm{~g}$ as many as 400 fish. These seeds were obtained in the village of Fold Fabric Kampar, Riau. This study used a one-factor completely randomized design method with 5 levels of treatment and 3 replications. The treatment was feeding the percentage of substitution of soybean flour with different fermented water hyacinth leaf flour, namely (100:0\%), (90:10\%), (80:20\%), (70:30\%), and $(60: 40 \%)$. The containers used in this study were cages measuring $1 \times 1 \times 1 \mathrm{~m}^{3}$ as many as 15 units, with a stocking density of 20 fish/container. The results showed that the use of fermented water hyacinth leaf flour as a feed ingredient for asian redtail catfish was able to reduce the use of soy flour, this could be seen from the average weight gain of asian redtail catfish fry each period. The use of fermented water hyacinth leaf flour in feed as much as $30 \%$ resulted in the best growth
\end{abstract}


of asian redtail catfish which resulted in feed efficiency of $46.64 \%$, protein retention of $18.73 \%$, specific growth rate of $3.85 \%$ and $99-100 \%$ survival.

Keyword: Hyacinth, Cow Rumen, Hemibagrus nemurus

\section{Pendahuluan}

Ikan baung (Hemibagrus nemurus) merupakan salah satu spesies catfish lokal yang populer dan harganya relatif mahal, 2-3 kali harga ikan patin atau lele (Hasan et al., 2001). Budidaya ikan baung saat ini sedang dikembangkan. Teknologi pembesaran ikan ini dengan pemberian pakan buatan telah berhasil, namun untuk pertumbuhan optimum dan mutu daging yang baik, ikan ini memerlukan protein yang tinggi dalam makanannya, untuk pembesaran skala budidaya diperlukan $34-42 \%$ protein (Khan et al., 1993). Suprayudi (2010), menyatakan bahwa tingginya harga pakan yang mencapai $60-70 \%$ total biaya budidaya menjadi tantangan dalam proses budidaya karena penyediaan bahan baku pakan berkualitas masih mengandalkan impor bahan baku terutama tepung ikan dan tepung kedelai. Salah satu upaya untuk mengurangi ketergantungan pada bahan baku impor adalah melakukan penggantian dengan bahan pakan lokal yang memiliki kandungan nutrien yang dibutuhkan ikan dalam jumlah yang cukup, harga relatif murah, tersedia dalam jumlah besar, tidak berkompetisi dengan manusia dan dapat menekan biaya pakan seperti daun eceng gondok.

Eceng gondok (Eichhornia crassipes) merupakan tanaman air yang dapat berkembang biak cepat dan mampu bersaing kuat dengan organisme perairan lainnya, sehingga tanaman ini umumnya disebut gulma. Keberadaan eceng gondok yang melimpah di perairan menjadikan tanaman ini sebagai salah satu kandidat bahan baku lokal yang sangat potensial untuk dijadikan pakan ikan. Eceng gondok memiliki nilai nutrisi cukup baik, dimana kandungan protein berkisar 9,8-15,7\%, abu 11,9-23,9\%, lemak kasar $1,1-3,3 \%$ dan serat kasar 16,8-24,6\% (Astuti, 2008). Kendala penggunaan tepung daun eceng gondok sebagai bahan baku pakan adalah zat anti-nutrisi berupa nitrat $0,3 \%$, oksalat $0,6 \%$ dan sianida $30 \mathrm{mg} / \mathrm{kg}$ basah (Muskita, 2012). Selain itu, eceng gondok juga mempunyai kandungan protein yang rendah serta kandungan serat kasar yang cukup tinggi. Oleh sebab itu, perlu dilakukan pengolahan sebelum digunakan sebagai bahan pakan. Untuk meningkatkan nilai gizi dan meningkatkan kecernaan eceng gondok yaitu dengan cara teknologi fermentasi (Fitrihidajati et al., 2015).

Cairan rumen sapi (CRS) mengandung karbohidrat, serat kasar, protein kasar serta enzim-enzim hydrolase untuk proses fermentasi. Cairan rumen sapi merupakan salah satu sumber bahan yang murah dan mudah diperoleh sebagai fermentor. Hasil penelitian Sibarani (2018) menyatakan bahwa fermentasi tepung eceng gondok menggunakan cairan rumen sapi dapat menurunkan serat kasar $21,12 \%$ menjadi $15,0 \%$. Berdasarkan uraian diatas maka peneliti tertarik untuk melakukan penelitian tentang pemanfaatan tepung daun eceng gondok difermentasi menggunakan cairan rumen sapi terhadap pertumbuhan ikan baung

\section{Metode Penelitian}

\subsection{Waktu dan Tempat}

Penelitian ini dilaksanakan pada bulan September sampai November 2019 di Balai Benih Ikan, Sei Tibun, Kabupaten Kampar, Pekanbaru.

\subsection{Metode Penelitian}

Metode yang digunakan adalah metode Rancangan Acak Lengkap (RAL) satu faktor dengan 5 taraf perlakuan dan 3 kali ulangan sehingga diperlukan 15 unit percobaan. Perlakuan yang digunakan mengacu pada penelitian Hutabarat (2017), yaitu:

$\mathrm{P} 0=$ Tepung Kedelai $100 \%$, Fermentasi Eceng Gondok $0 \%$

$\mathrm{P} 1=$ Tepung Kedelai $90 \%$, Fermentasi Eceng Gondok $10 \%$

P2 $=$ Tepung Kedelai $80 \%$, Fermentasi Eceng Gondok $20 \%$

P3 = Tepung Kedelai 70\%, Fermentasi Eceng Gondok $30 \%$

P4 = Tepung Kedelai $60 \%$, Fermentasi Eceng Gondok $40 \%$ 


\subsection{Prosedur Penelitian}

\subsubsection{Persiapan Daun Eceng Gondok}

Eceng gondok diambil daunnya, kemudian daun eceng gondok tersebut direndam selama 24 jam pada air mengalir untuk mengurangi zat anti nutrisi yang terkandung pada daun eceng gondok. Setelah direndam, daun eceng gondok dipotong kecilkecil dan dijemur di bawah sinar matahari hingga kering. Setelah itu daun eceng gondok dihaluskan untuk dijadikan tepung, untuk menghasilkan $1 \mathrm{~kg}$ tepung daun eceng gondok dibutuhkan kurang lebih $6 \mathrm{~kg}$ daun eceng gondok basah.

\subsubsection{Persiapan Starter Rumen Sapi}

Cairan rumen diambil dari Rumah Potong Hewan (RPH) di Jalan Cipta Karya Ujung Pekanbaru. Bahan yang digunakan dalam pembuatan starter isi rumen adalah isi rumen sapi segar 100 gram, gula merah $200 \mathrm{~g}$ dan air 5 L. Cara pembuatan starter isi rumen mengacu kepada Wuryantoro (2000) yaitu Air (air yang tidak mengandung bahan kimia seperti kaporit) disiapkan sebanyak 5 liter ke dalam ember plastik bewarna gelap, lalu rumen sapi dimasukkan sebanyak 100 gram ke dalam ember yang telah berisi air, selanjutnya gula merah yang sudah dihancurkan sebanyak 200 gram dimasukan ke dalam air disediakan dalam ember, untuk selanjutnya air yang sudah tercampur gula merah dan rumen sapi diaduk hinga tercampur rata dan ember ditutup plastik kedap udara dan diinkubasi selama 24-36 jam, dan terakhir starter siap digunakan apabila ada gelembung gas yang mengambang di atasnya, warna putih atau buih-buih yang mengambang di permukaan wadah dan menghasilkan aroma khas seperti aroma tape fermentasi.

\subsubsection{Pembuatan Pakan Uji}

Pakan uji yang akan dibuat, ditentukan terlebih dahulu formulasi dan komposisi masing-masing bahan sesuai dengan kebutuhan protein yang diharapkan yaitu $33 \%$, proporsi fermentasi tepung daun eceng gondok ditentukan sesuai dengan kebutuhan masing-masing perlakuan, sedangkan bahanbahan lain disesuaikan jumlahnya berdasarkan hasil perhitungan.

\subsubsection{Pemeliharaan Ikan Uji}

Ikan uji yang digunakan dalam penelitian ini adalah benih ikan baung yang berukuran $5 \mathrm{~cm}$ dengan rata-rata bobot awal $1,26 \pm 1,17$ g. Wadah yang digunakan pada penelitian ini adalah keramba yang berukuran $1 \times 1 \times 1 m^{3}$ sebanyak 15 unit dengan padat tebar20 ekor/wadah. Selama pemeliharaan ikan diberikan pakan 3 kali sehari yaitu pada pukul $07.00,12.00$, dan 17.00 sebanyak $10 \%$ dari biomassa ikan uji. Setiap 14 hari sekali ikan ditimbang untuk menyesuaikan jumlah pakan. Pemeliharaan ikan dilakukan selama 56 hari.

\subsection{Parameter yang Diamati \\ 2.4.1. Efisiensi Pakan}

Menurut Watanabe (1988) rumus menghitung efisiensi pakan yaitu:

Keterangan:

$$
\mathrm{EP}=\frac{(\mathrm{Bt}+\mathrm{Bd})-\mathrm{Bo}}{\mathrm{F}} \times 100 \%
$$

$\mathrm{EP}=$ Efisiensi Pakan (\%)

$\mathrm{Bt}=$ Bobot biomassa ikan pada akhir penelitian $(\mathrm{g})$

Bo = Bobot biomassa ikan pada awal penelitian $(\mathrm{g})$

$\mathrm{Bd}=$ Bobot biomassa ikan lyang mati selama penelitian $(\mathrm{g})$

$\mathrm{F} \quad=$ Jumlah pakan yang dikonsumsi ikan selama penelitian $(\mathrm{g})$

\subsubsection{Retensi Protein}

Retensi protein dapat dihitung dengan rumus Watanabe (1988):

$\mathrm{RP}=\frac{\text { Pertambahan bobot protein tubuh }(\mathrm{g})}{\text { Bobot total protein yang dikonsumsi }(\mathrm{g})} \times 100 \%$

\subsubsection{Laju Pertumbuhan Spesifik}

Menurut Hadadi et al., (2007) laju pertumbuhan spesifik diukur dengan menggunakan rumus

$$
\mathrm{LPS}=\frac{(\mathrm{Ln} \mathrm{Wt}-\mathrm{Ln} \mathrm{Wo})}{\mathrm{t}} \times 100 \%
$$

Keterangan:

$$
\begin{aligned}
\mathrm{LPS} & =\text { Laju pertumbuhan spesifik }(\%) \\
\mathrm{Wt} & =\text { Bobot rata-rata ikan pada akhir } \\
\text { penelitian }(\mathrm{g}) & \\
\mathrm{W} 0 & =\begin{array}{l}
\text { Bobot rata-rata ikan pada awal } \\
\text { penelitian }(\mathrm{g})
\end{array} \\
\mathrm{t} & =\text { Lama penelitian (hari). }
\end{aligned}
$$




\subsubsection{Tingkat Kelulushidupan}

Menurut Menurut Effendie (1997), tingkat kelulushidupan dapat dihutung dengan rumus sebagai berikut:

$$
\mathrm{SR}=(\mathrm{Nt} / \mathrm{No}) \times 100 \%
$$

Keterangan:

$\mathrm{SR}=$ Kelulushidupan $(\%)$

$\mathrm{Nt}=$ Jumlah ikan yang hidup pada akhir penelitian (ekor)

No $=$ Jumlah ikan yang hidup pada awal penelitian (ekor)

\subsubsection{Kualitas Air}

Untuk menunjang data kelulushidupan dilakukan kualitas air, parameter yang dilakukan selama penelitian adalah suhu, $\mathrm{pH}$, Oksigen terlarut (DO) yang dilakukan pada awal, pertengahan dan akhir penelitian.

\subsection{Analisis Data}

Data yang diperoleh selama penelitian disajikan dalam bentuk tabel kemudian dihitung laju pertumbuhan, efisiensi pakan, kelulushidupan dan retensi protein. Untuk mengetahui pengaruh perlakuan terhadap parameter dianalisa dengan uji statistik dengan menggunakan analisis varian (ANAVA). Sedangkan data kualitas air di analisa secara deskriptif.

\section{Hasil dan Pembahasan \\ 3.1. Efisiensi Pakan}

Nilai efisiensi pakan menunjukkan baik dan buruknya kualitas pakan buatan yang diberikan. Efisiensi pakan dapat diartikan sebagai kemampuan ikan dalam memanfaatkan pakan yang diberikan sehingga ikan dapat tubuh dan berkembang. Efisiensi pakan selama penelitian berkisar 39,1546,64\%. Efisiensi pakan benih ikan baung yang diberikan pada perlakuan P1, P2, P3, dan $\mathrm{P} 4$, lebih tinggi nilainya dibandingkan dengan nilai efisiensi pakan pada perlakuan P0. Hal ini karena pakan mengandung tepung eceng gondok terfermentasi yang mampu dimanfaatkan oleh ikan dan juga dengan adanya enzim-enzim yang terdapat dalam tepung eceng gondok yang difermentasi menggunakan cairan rumen sapi yang mampu meningkatkan daya cerna ikan. Dari hasil penelitian diperoleh rata-rata nilai efisiensi pakan yang dapat dilihat pada Tabel 1 .

Tabel 1. Efisiensi Pakan Ikan Baung (H. nemurus) Pada Setiap Perlakuan Selama Penelitian

\begin{tabular}{cccccc}
\hline \multirow{2}{*}{ Ulangan } & \multicolumn{5}{c}{ Perlakuan (\% TK : TDEGF) } \\
\cline { 2 - 6 } & P0 (100:0) & P1 (90:10) & P2 (80:20) & P3 (70:30) & P4 (60:40) \\
\hline 1 & 39,45 & 40,49 & 40,26 & 46,09 & 39,88 \\
2 & 39,01 & 40,18 & 39,79 & 46,31 & 38,90 \\
3 & 39,33 & 40,72 & 39,31 & 47,52 & 38,66 \\
\hline Jumlah & 117,80 & 121,39 & 119,35 & 139,92 & 117,44 \\
\hline Rata-rata & $39,27 \pm 0,22^{\mathrm{a}}$ & $40,46 \pm 0,27^{\mathrm{b}}$ & $39,78 \pm 0,45^{\mathrm{ab}}$ & $46,64 \pm 0,77^{\mathrm{c}}$ & $39,15 \pm 0,64^{\mathrm{a}}$ \\
\hline
\end{tabular}

Keterangan: Nilai yang tertera merupakan rata-rata \pm standar deviasi, huruf yang berbeda pada baris yang sama menunjukkan adanya perbedaan nyata antar perlakuan; TDEGF= Tepung daun eceng godok terfermentasi, TK= Tepung kedelai

Ahmadi et al. (2012) mengatakan pakan dapat dikatakan baik apabila nilai efisiensi pemberian pakan lebih dari $50 \%$ atau bahkan mendekati $100 \%$. Nilai efisiensi pakan tertinggi pada P3 yaitu sebesar $46,64 \%$. Dari hasil uji analisis variansi (ANAVA) $\mathrm{P}<0,05$ artinya ada pengaruh pemberian tepung daun eceng gondok terfermentasi menggunakan cairan rumen sapi terhadap efisiensi pakan benih ikan baung, sehingga dilkukan uji lanjut untuk mengetahui pengaruh antar perlakuan. Hasil uji lanjut yang menunjukkan bahwa P3 $(46,64 \%)$ berbeda nyata terhadap semua perlakuan.
Nilai efisiensi pakan tertinggi pada P3 hal ini diduga bahwa benih ikan baung mampu memanfaatkan dan mencerna pakan yang diberikan dengan baik, dimana hasil tersebut sesuai dengan nilai kecernaan pada P3 yang memilki nilai kecernaan tertinggi yaitu sebesar 60,63\% (Tabel 1). Menurut Ugwuanyi et al. (2009) menyatakan bahwa efisiensi pakan diperiksa guna menilai kualitas pakan, semakin tinggi nilai efisiensi pakan membuktikan pakan semakin baik. Selanjutnya Afrianto dan liviawary, (2009) mengatakan bahwa pakan yang mudah dicerna akan lebih efisien dimanfaatkan oleh ikan 
karena nutrisi pakan akan lebih mudah diserap oleh tubuh.

Efisiensi pakan pada penelitian ini berkisar 39,15-46,64\%, dimana nilai efisiensi ini tergolong baik. Berdasarkan penelitian Hutabarat, (2017) dengan penambahan tepung eceng gondok yang difermentasi menggunakan rumen sapi dalam pakan untuk pertumbuhan benih ikan bawal air tawar mengahasilkan nilai efisiensi pakan 49,290,8\%. Rahmad (2017) dengan penambahan tepung eceng gondok terfermentasi menggunkan cairan rumen sapi dalam pakan untuk pertumbuhan benih ikan jelawat menghasilkan efisiensi pakan sekitar 31,1$41,7 \%$, dan Syarifah (2014) menghasilkan nilai efisiensi pakan sekitar 10,17-29,81\% dengan pemanfaatkan eceng gondok terfementasi pada pakan benih ikan baung.

\subsection{Retensi Protein}

Retensi protein merupakan perbandingan antara jumlah protein yang disimpan dalam tubuh ikan selama penelitian dengan jumlah protein yang diberikan melalui pakan. Retensi protein ini juga merupakan perbandingan antara banyaknya jumlah protein yang diberikan melalui pakan dan dimanfaatkan untuk pembangunan atau memperbaiki sel-sel tubuh yang rusak. Data nilai perhitungan retensi protein selama penelitian dapat dilihat pada Tabel 2.

Tabel 2. Retensi Protein Ikan Baung pada Setiap Perlakuan Selama Penelitian

\begin{tabular}{cccccc}
\hline Ulangan & \multicolumn{5}{c}{ Perlakuan (\% Tk : TDEGF) } \\
\cline { 2 - 6 } & P0 (100:0) & P1 (90:10) & P2 (80:20) & P3 (70:30) & P4 (60:40) \\
\hline 1 & 15.38 & 16.42 & 15.54 & 18.90 & 15.52 \\
2 & 15.20 & 16.29 & 15.35 & 18.58 & 15.52 \\
3 & 15.33 & 16.50 & 15.18 & 18.70 & 15.42 \\
\hline Jumlah & 45.91 & 49.22 & 46.07 & 56.18 & 46.45 \\
\hline Rata-rata & $15.30 \pm 0.92^{\mathrm{a}}$ & $16.41 \pm 0.10^{\mathrm{b}}$ & $15.36 \pm 0.18^{\mathrm{a}}$ & $18.73 \pm 0.16^{\mathrm{c}}$ & $15.48 \pm 0.05^{\mathrm{a}}$ \\
\hline
\end{tabular}

Berdasarkan hasil uji analisis variansi (ANAVA) menunjukkan ada pengaruh penggunaan tepung daun eceng gondok terfermentasi menggunakan cairan rumen sapi terhadap retensi protein $\mathrm{P}>0,05$, sehingga dilakukan uji lanjut untuk mengetahui pengaruh antar perlakuan. Hasil uji lanjut Student Newman Keuls yang menunjukkan bahwa P3 (18,73\%) berbeda nyata terhadap perlakukan lainnya.

Tabel 2 dapat dilihat bahwa retensi protein tertinggi terdapat pada perlakuan P3 yaitu $18.73 \%$. Hal ini terjadi karena pakan pada perlakuan ini lebih disukai ikan dan mudah dicerna dengan baik oleh benih ikan baung. Hal ini sesuai dengan pendapat Dani $e t$ al. (2005) bahwa protein yang terkandung dalam pakan ikan berhubungan langsung dalam mendukung sintesa protein dalam tubuh, meningkatkan protein dalam tubuh berarti ikan telah mampu memanfaatkan protein yang diberikan secara optimal. Hal ini bisa dilihat dari nilai efisiensi pakan pada P3 memiliki nilai rata-rata tertinggi sebesar 46,64\%. Selain itu, diduga komposisi pakan pada perlakuan ini lebih sesuai untuk benih ikan baung sehingga mampu memanfaatkan protein pakan untuk meningkatkan protein tubuh ikan.

Kandungan protein pada P3 yaitu, $33,98 \%$ menunjukkan bahwa pakan dengan penambahan tepung eceng gondok terfermentasi sebanyak 30\% ini adalah pakan yang sesuai dengan kebutuhan ikan baung, sehingga mampu diserap tubuh ikan baung secara optimal dan juga dengan adanya bantuan proses fermentasi yang mampu meningkatkan daya cerna pakan. Suwarsorto dan Anggoro (2005) mengatakan bahwa makanan yang telah difermentasi memiliki nilai gizi yang lebih tinggi dan daya cerna tinggi sehingga memungkinkan diserap oleh tubuh lebih banyak dan energi yang tersedia dalam tubuh ikan akan lebih tinggi, serat memiliki aroma khas.

Nilai retensi protein terendah terdapat pada P0 yaitu sebesar $15,30 \%$ atau pakan yang dibuat tanpa penambahan tepung eceng gondok terfermntasi. Hal ini disebabkan karena pakan pada perlakuan ini tidak sesukai oleh ikan, diikuti dengan nilai kecernaan dan efisiensi pakan yang terendah terdapat pada perlukuan P0. Selain itu, pakan pada P0 memiliki kandungan serat kasar yang tinggi, hal ini mengakibatkan rendahnya kemampuan 
ikan mencerna nutrien dalam pakan sehingga protein yang diserap tubuh ikan dari pakan yang diberikan sedikit. Hal ini juga menujukkan banyaknya protein yang tersedia bagi sintesis protein yang rendah, dan apabila sintesis protein rendah akan menyebabkan protein yang disimpan dalam tubuh akan lebih kecil. Seperti yang digambarkan oleh nilai retensi protein pada perlakuan $\mathrm{P} 0$.

Retensi protein ini lebih baik bila dibandingkan dengan cahyadi (2015) dengan penambahan tepung eceng gondok fermentasi sebagai pakan ikan jelawat menghasilkan retensi protein 4,05-11,99\%. Rahmad (2017) dengan penambahan tepung eceng gondok terfermentasi menggunakan rumen sapi sebagai bahan pakan ikan jelawat menghasil kan rensi protein 7,05-17,08\% dan Suharman et al., (2014) menyatakan bahwa nilai retensi protein beriksar 12,23-19,52\% dengan penambahan eceng gondok terfermentasi sebagai bahan baku dalam pembuatan pakan ikan baung

\subsection{Laju Pertumbuhan Spesifik}

Kualitas pakan yang baik dan sangat dibutuhkan ikan untuk tumbuh dan berkembang secara maksimal, kulitas dari pakan uji yang digunakan pada penelitian ini terlihat dari hasil kinerja pertumbuhan yang didukung berdasarkan pemanfaatan pakan oleh ikan baung. Laju pertumbuhan ikan yang tinggi disertai dengan konsumsi pakan yang efisien, akan menghasilkan nilai efisien pakan yang tinggi (Kurniasih et al., 2012). Pertumbuhan didefinisikan sebagai proses perubahan ukuran (berat, panjang atau volume) pada priode waktu tertentu (Affandi dan Tang, 2002). Perubahan bobot rata-rata individu ikan uji pada setiap perlakuan selama penelitian dapat dilihat dari Gambar 1.

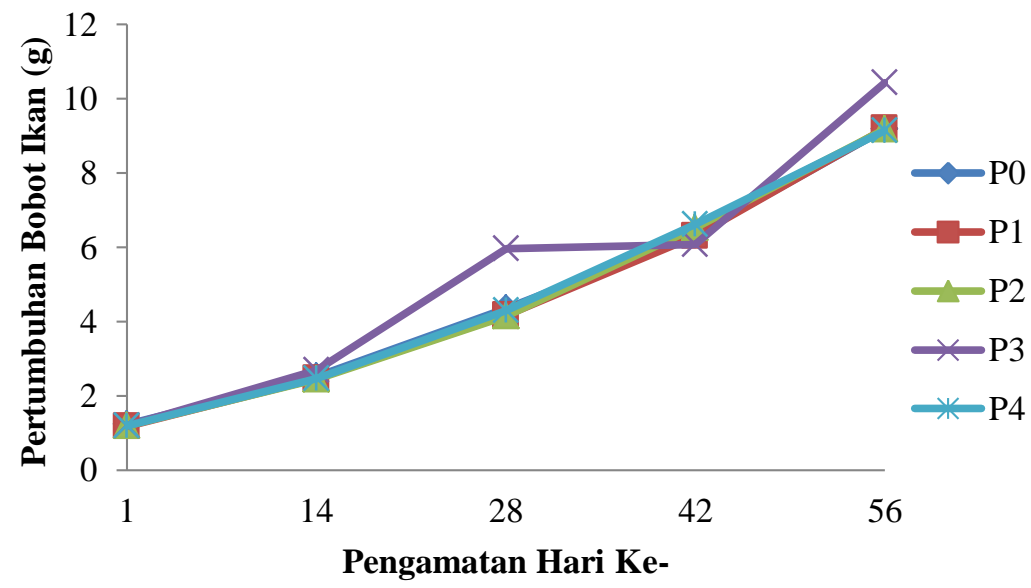

\section{Gambar 1. Perubahan Bobot Rata-rata Individu Ikan Baung (H. nemurus) pada setiap perlakuan selama penelitian}

Berdasarkan pengamatan terhadap benih ikan baung selama 56 hari masa pemeliharaan diketehui bahwa perbedaan tingkat penggunaan tepung daun eceng gondok terfermentasi dalam pakan buatan menghasilkan pertumbuhan bobot individu benih ikan baung yang berbeda. Bobot individu benih ikan baung meningkat seiring dengan bertambahnya waktu pemeliharaan. Pada Gambar 4 dapat dilihat bahwa pada pemeliharaan 14 hari pertama pertumbuhan rata-rata bobot ikan baung masih relatif sama dan belum menjukkan pertumbuhan yang terlalu signifikan, hal ini karena benih ikan baung masih dalam masa adaptasi dengan lingkungan dan pakan yang diberikan. Pada hari ke 15 sampai 56 hari terlihat bahwa P3 memiliki pertumbuhan lebih tinggi dari perlakuan lainnya. Hal ini menunjukkan bahwa ikan uji pada perlakukan tersebut dapat menerima dan memanfaatkan pakan uji yang diberikan untuk pertumbuhannya.

Pertambahan bobot benih ikan menunjukkan adanya proses pertumbuhan pada benih ikan baung menggambarkan bahwa pakan yang diberikan mampu dimanfaatkan dalam proses pertumbuhannya. Pertumbuhan ikan pada setiap sampling mengalami kenaikan disebabkan oleh faktor internal dan eksternal. Menurut Soesono (1984) dalam Agustono (2014), yaitu internal diantaranya keturunan, jenis kelamin, umur, 
dan penyakit sedangakan yang termasuk faktor eksternal adalah pakan dan kualitas perairan di sekitar wadah pemeliharaan. Pakan sebagai faktor eksternal memiliki peran yang sangat penting bagi pertumbuhan, pakan yang dapat dimanfaatkan dengan baik oleh ikan akan menghasilkan pertumbuhan yang baik. Hasil pengamatan terhadap laju pertumbuhan spesifik benih ikan baung pada setiap perlakuan selama penelitian yang dapat dilihat pada Tabel 3.

Tabel 3. Laju Pertumbuhan Spesifik individu ikan baung pada setiap perlakuan selama penelitian

\begin{tabular}{cccccc}
\hline \multirow{2}{*}{ Ulangan } & \multicolumn{5}{c}{ Perlakuan (\% TK : TDEGF) } \\
\cline { 2 - 6 } & P0 (100:0) & P1 (90:10) & P2 (80:20) & P3 (70:30) & P4 (60:40) \\
\hline 1 & 3,58 & 3,70 & 3,64 & 3,87 & 3,60 \\
2 & 3,55 & 3,65 & 3,62 & 3,85 & 3,65 \\
3 & 3,60 & 3,64 & 3,67 & 3,84 & 3,66 \\
\hline Jumlah & 10,73 & 10,99 & 10,92 & 11,56 & 10,91 \\
\hline Rata - rata & $3,58 \pm 0,02$ & $3,66 \pm 0,03$ & $3,64 \pm 0,02$ & $3,87 \pm 0,01$ & $3,64 \pm 0,01$ \\
\hline
\end{tabular}

Laju pertumbuhan spesifik ikan baung yang diperoleh selama ini berkisar 3,56$3,87 \%$. Dari hasil uji analisis variansi (ANAVA) diperoleh penggunaan tepung daun eceng gondok terfermentasi dengan cairan rumen sapi yang digunakan dalam pakan tidak berpengaruh terhadap pertumbuhan spesifik ikan.

Laju pertumbuhan spesifik pada penelitian ini lebih baik dibandingkan dengan penelitian yang telah dilakukan sebelumnya. Mohaptra (2015) pemanfaatkan tepung eceng gondok sebagai pengganti protein dalam pakan ikan mas, memperoleh laju pertumbuhan spesifik sekiar $0,5-0,8 \%$, Cahyadi (2015) memperoleh laju pertumbuhan spesifik sebesar $2,18 \%$ dengan perlakuan $30 \%$ tepung eceng gondok terfermentasi, dan Rahmad (2017) dengan pemanfaatan tepung eceng gondok terfermentasi menggunakan cairan rumen sapi dalam bakan ikan jelawat memperoleh nilai laju pertumbuhan spesifik $0,6 \%$.

Rendahnya nilai laju pertumbuhan spesifik P0 diduga karena pakan yang masuk kedalam lambung tidak dapat dicerna dengan sempurna oleh usus dan nutrisi dalam pakan tidak diserap secara optimal dibandingkan perlakuan lainnya. Selain itu, diduga karena tidak adanya penambahan tepung daun eceng gondok terfermentasi pada pakan tersebut mengakibatkan kandungan nutrien yang ada pada pakan tersebut lebih sedikit dari pada pakan yang diberikan tepung daun eceng gondok terfermentasi. Hal ini membuktikan bahwa pakan yang difermentasi mempengaruhi tingkat laju pertumbuhan spesifik pada benih ikan baung disebabkan proses fermentasilah yang mampu merubah substrat bahan tumbuhhan yang sulit dicerna menjadi lebih mudah dicerna. Sesuai dengan yang dikatakan Adelina et al. (2009) yang menyatakan fermentasi merupakan suatu proses untuk meningkatkan daya cerna karena bahan yang telah difermentasi dapat mengubah bahan tumbuhan yang susah dicerna menjadi protein sel tunggal.

Fermentasi pada pakan ikan membuat kandungan nutrisi pakan menjadi lebih baik dan mudah dimanfaatkan oleh ikan, zat-zat nutrisi yang dibutuhkan adalah protein, lemak, karbohidrat, vitamin dan mineral (Handajani dan Widodo, 2010). Menurut Lovell dalam Suprayudi et al. (2014) mengatakan bahwa pertumbuhan atau pembentukkan jaringan tubuh paling besar dipengaruhi oleh kesimbangan protein dan energi dalam pakan ikan. fermentasi juga mampu menambahkan cita rasa pakan dan menghasilka bau tertentu serta mampu merangsang selera makan ikan sehingga jika bahan yang difermentasi lebih banyak dalam pakan akan mengurangi energi untuk pencernaan dan mengalihkannya untuk proses pertumbuhan

\subsection{Kelulushidupan Ikan Baung (H.nemurus)}

Kelulushidupan adalah perbandingan antara jumlah organisme yang hidup pada akhir priode dengan jumlah organisme yang hidup di awal proade penelitian. Kelulushidupan ikan dapat diketahui dengan mengamati jumlah ikan yang hidup pada awal dan akhir penelitian dan dinyatakan dalam 
persen (\%). Kelangsungan hidup dapat dilakukan sebagai tolak ukur untuk mengetahui toleransi dan kemampuan ikan untuk hidup. Berdasarkan hasil uji analisis variansi (ANAVA) penggunaan tepung daun eceng gondok yang difermentasi menggunakan rumen sapi dalam pakan tidak berpangaruh nyata terhadap kelulushidupan benih ikan baung dengan nilai probabilitas $\mathrm{P}>0,05 \%$. Adapun data hasil perhitungan kelulushidupan ikan baung dapat dilihat pada Tabel 4.

Tabel 4. Kelulushidupan (\%) Benih Ikan Baung (H. nemurus) Selama Penelitian

\begin{tabular}{cccccc}
\hline \multirow{2}{*}{ Ulangan } & \multicolumn{5}{c}{ Perlakunan $(\%$ TK: TDEGF) } \\
\cline { 2 - 6 } & P0 (100:0) & P1 (90:10) & P2 (80:20) & P3 (70:30) & P4 (60:40) \\
\hline 1 & 100 & 100 & 100 & 100 & 100 \\
2 & 100 & 100 & 100 & 100 & 100 \\
3 & 100 & 100 & 100 & 100 & 99 \\
\hline Jumlah & 300 & 300 & 300 & 300 & 296 \\
\hline Rata - rata & $100 \pm 0,00^{\mathrm{a}}$ & $100 \pm 0,00^{\mathrm{a}}$ & $100 \pm 0,00^{\mathrm{a}}$ & $100 \pm 0,00^{\mathrm{a}}$ & $99 \pm 2,30^{\mathrm{a}}$ \\
\hline
\end{tabular}

Angka kelulushidupan ikan baung diperoleh selama penelitian berkisar antara 99-100\%. Tingginya kelulushidupan benih ikan baung pada penelitian ini disebabkan karena pakan yang diberikan pada penelitian ini memiliki komponen bahan penyusun yang mendekati kebutuhan ikan baung yang akan mempermudah dalam proses metabolisme dan penyerapan nutrisinya. Selain itu kualitas air yang baik selama penelitian juga sangat mendukung kelangsungan hidup. Sedangkan mortalitas ikan disebabakan karena kesalahan pada saat sampling yang tidak disengaja.

\subsection{Kualitas Air}

Pengukuran terhadap panjang cangkang Berdasarkan penelitian yang telah dilakukan, di dapat hasil kualitas air (suhu, $\mathrm{pH}$, dan DO) pemeliharaan benih ikan baung yang dpat dilihat pada Tabel 5 .

Tabel 5. Hasil Pengukuran Kualitas Air Selama Penelitian

\begin{tabular}{ccccc}
\hline \multirow{2}{*}{ Parameter } & \multicolumn{4}{c}{ Kisaran } \\
\cline { 2 - 5 } & Awal & Pertengahan & Akhir & Baku mutu (SNI 2009) \\
\hline Suhu $\left({ }^{0} \mathrm{C}\right)$ & $27-32$ & $27-31$ & $27,5-32$ & $25-32$ \\
$\mathrm{pH}$ & $6-7$ & $6,5-7$ & $6-7$ & $6-8$ \\
$\mathrm{DO}(\mathrm{mg} / \mathrm{l})$ & $5-6,4$ & $5,2-6,2$ & $5,5-6,5$ & $>3$ \\
\hline
\end{tabular}

Berdasarkan data pengukuran kualitas air pada Tabel 10 dapat diketehui bahwa kualitas air yang digunakan dalam penelitian ini masih berada dalam kisaran batas optimum. Suhu selama penelitian ini berkisar antara $27-32^{\circ} \mathrm{C}$ pada semua perlakuan. Perubahan suhu dikarenakan adanya kondisi perubahan cuaca yang tidak stabil. Berdasarkan baku mutu SNI (2009) kisaran kualitas air secara khusus dalam pemeliharaan ikan baung untuk suhu adalah $25-32^{\circ} \mathrm{C}$.

Lesmana (2001) mengatakan bahwa suhu yang terlalu besar akan menyebabkan beberapa pengaruh terhadap kesehatan ikan karena bila suhu terlalu rendah maka akan kurang aktif, nafsu makan menurun sehingga laju metabolisme pun menurun. Sebaliknya jika suhu terlalu tinggi, maka ikan akan aktif, nafsu makan meningkat sehingga kebutuhan oksigen pun akan meningkat serta laju metabolisme pun akan meningkat. Delami (2001) juga menyatakan bahwa perubahan suhu yang sangat mendadak sebesar $5^{\circ} \mathrm{C}$ dapat menyebabkan ikan stress.

Derajat keasaman $(\mathrm{pH})$ sangat berpengaruh terhadap pertumbuhan ikan di perairan. Dalam penelitian yang telah dilakukan didapatkan $\mathrm{pH}$ berkisar antara 6-7. Nilai $\mathrm{pH}$ yang terlalu rendah dan tinggi dapat mematikan ikan. menurut Cahyono (2000) derajat keasaman $(\mathrm{pH})$ air dapat mempengaruhi pertumbuhan ikan. derajat keasaman air yang rendah atau sangat asam dapat menyebabkan kematian ikan dan keadaan air basa juga menyebabkan pertumbuhan ikan terhambat. Adapun $\mathrm{pH}<5,5$ akan menjadi racun (toksin) bagi kebanyakan ikan dikolam dan $\mathrm{pH}>9$ juga berbahaya sekali bagi kehiduapan ikan. Menurut Syafriadiman et al. (2005) pH yang ideal untuk budidaya 
perairan yang ideal yaitu berkisar antara 5-9. Dan Kodi (2015) menyatakan bahwa untuk nilai optimal kualitas budidaya ikan baung seperti $\mathrm{pH}$ berkisar antara 6,5-8,5.

Kandungan oksigen terlarut (DO) pada pemeliharaan ikan baung selama penelitian ini yaitu bekisar 5-6,5 mg/L. Effendi (2003) mengatakan bahwa perairan yang digunakan dalam kepentingan perikanan sebaiknya memiliki konsentrasi oksigen terlarut tidak kurang dari $5 \mathrm{mg} / \mathrm{L}$. Kordi (2015) juga menyatakan untuk nilai optimum oksigen terlarut pada pemeliharaan ikan baung bekisar antara 3-7 mg/L. Dari hasil yang diperoleh selama penelitian nilai oksegen terlarut sudah dalam nilai optimal untuk pemeliharaan ikan baung.

\subsection{Analisis Biaya Pakan Uji}

Analisis biaya pakan uji (dalam $1 \mathrm{~kg}$ ) pakan pada setiap perlakuan dapat dihitung berdasarkan jumlah dan komposisi bahan yang digunakan dalam rincian biaya Biaya pembuatan pakan setiap perlakuan dapat dilihat pada Tabel 6.

Tabel 6. Rincian Biaya Pembuatan Pakan Berdasarkan Perlakuan

\begin{tabular}{cc}
\hline $\begin{array}{c}\text { Perlakuan (\% TK : } \\
\text { TDEGF) }\end{array}$ & Biaya $(\mathrm{Rp} / \mathrm{kg})$ \\
\hline P0 (100:0) & 8.950 \\
P1 (90:10) & 8.952 \\
P2 (80:20) & 8.854 \\
P3 (70:30) & 8.732 \\
P4 (60:40) & 8.588 \\
\hline
\end{tabular}

Tabel 6 dapat dilihat bahwa biaya termurah pembuatan pakan terdapat pada perlakuan P4 yaitu Rp. $8.588,-/ \mathrm{kg}$. Hal ini disebabkan pada perlakuan P4 lebih banyak menggunakan tepung daun eceng gondok terfermentasi dari pada perlakuan lainnya. Bahan-bahan pakan yang digunakan harganya relatif murah serta mampu memanfaatkan bahan-bahan lokal untuk mengurangi biaya pembelian bahan pakan. Secara ekonomis perlakuan yang dimanfaatkan tepung daun eceng gondok terfermentasi lebih menguntungkan dari pada pakan kontrol yang tidak menggunakan tepung daun eceng gondok terfermentasi. Biaya untuk pakan kontrol lebih mahal yaitu Rp. 8.950.,-/kg jika dibandingkan harga pelet komersil harganya cukup jauh yaitu pelet F99 dengan harga Rp. 15.000.,-/kg. Namun jika dilihat dari segi pemanfaatan untuk pertumbuhan, pakan yang menggunakan tepung daun eceng gondok terfermentasi $30 \% \quad(\mathrm{P} 3)$ lebih baik dibandingkan dengan $\mathrm{P} 4$ dengan harga $\mathrm{Rp}$. 8.736.,-/kg.

\section{Kesimpulan dan Saran}

Berdasarkan hasil penelitian yang telah dilkukan dapat disimpulkan bahwa fermentasi tepung eceng gondok menggunakan cairan rumen sapi dalam pakan mampu mengurai penggunaan tepung kedelai serta mampu dimanfaatkan benih ikan baung dengan baik dan optimal. Hasil analisis statistika menunjukkan tepung kedelai dengan tepung eceng gondok terfermentasi dalam pakan buatan memberikan pengaruh nyata terhadap efisiensi pakan, retensi protein serta laju pertumbuhan spesifik benih ikan baung. Perlakuan terbaik pada penelitian ini yaitu, tepung kedelai $70 \%$ : tepung daun eceng gondok $30 \%$, memberikan hasil terbaik terhadapa efisiensi pakan $(46,64 \%$,$) , retensi$ protein $(18,73 \%)$, laju pertumbuhan spesifik $(3,85 \%)$ dan kelulushidupan (99-100\%).

Sebaiknya dilakukan penelitian lanjutan tentang memanfaatan tepung daun eceng gondok dalam pakan terhadap jenis ikan lainnya dengan melakukan peningkatan dosis.

\section{Daftar Pustaka}

Adelina., dan Boer, I. (2009). Penggantian Tepung Ikan dengan Tepung Bekicot (Achatina fulica) dan Keong Mas dalam Pakan dan Pengaruhnya terhadap Pertumbuhan Benih Ikan Selais (Ompok hypopthalmus). Laporan Penelitian, Universitas Riau. $50 \mathrm{hlm}$

Afrianto, E., dan Liviawaty, E. (2009). Pakan ikan dan pengembangannya. Kanasius. Yogyakarta. $34 \mathrm{hlm}$.

Affandi, R., dan Tang, U.M. (2002). Fisiologi Hewan Air. Riau (ID). Universitas Riau.

Ahmadi, H. Iskandar, dan N. Kurniwati. (2012). Pemberian Probiotik dalam Pakan terhadap Pertumbuhan lele Sangkuriang (Clarias gariepinus) Pada Pendederan II. Jurnal Perikanan dan Kelautan, 3(4) :99-107.

Astuti, R.D. (2008). Analisis Kandungan Nutrisi pada Eceng Gondok. Institut Peratabian Bogor. Bogor. 18 hlm. 
Cahyadi, R. (2015). Penembahan Tepung eceng gondok (Eichhornia crassipes) fermentasi dalam pakan untuk pertumbuhan benih ikan jelawat (Leptobarbus hoeveni). Skripsi. Fakultas Perikanan dan Ilmu Kelautan. Universitas. Riau. Pekanbaru. $16 \mathrm{hlm}$.

Cahyono B. (2000). Budidaya Ikan Air Tawar. Kanisius. Yogyakarta

Chusniati, S.P. Kusriningrum, Mustikoweni, dan M. Lamid. (2005). Pengaruh Lama Pemeraman Jerami padi yang difermentasi oleh Isolasi bakteri Selulotik Rumen Terhadap Kandungan Protein Kasar dan Serat Kasar. Lembaga Penelitian. Universitas Airlangga. Surabaya. $33 \mathrm{hlm}$.

Dani, N.P., Budiraharjo, A. dan Listiyawati, S. (2005). Komposisi Pakan Buatan untuk Meningkatkan Pertumbuhan dan Kandungan Protein Ikan Tawes (Puntius javanicus Blkr). J. BioSMART. 7(2): 83-90.

Effendie, I. (1997). Biologi Prikanan. Yayasan Pustaka Nusantara. $163 \mathrm{hlm}$.

Fitrihidajati, H. Ratna, E. Isnawati dan Soeparto, G. (2015). Kualitas Hasil Fermentasi pada Pakan Ternak Ruminansia Berbahan Baku Eceng Gondok (Eichornia crassipes). Journal of Biology \& Education. Biosaintifika. 7 (1).

Hasan, B., Saad, C.R., Alimon, A.R., Kamarudin, M.S., Hassan Z. (2001). Replacement of fishmeal with co dried fish silage in the diet for Hemibagrus nemurus. Malaysian Journal of Animal Science 7: 6979.

Hutabarat, H.D. (2017). Pemanfaatan Tepung Daun Eceng Gondok (Eichhornia crassipes) Terfermentasi Menggunakan Cairan Rumen Sapi Dalam Pakan Terhadap Pertumbuhan Benih Ikan Bawal Bintang Air Tawar (Colossoma macropomum). Skripsi. Fakultas Perikanan dan Kelautan. Universitas Riau. Pekanbaru. 16 hlm.

Hadadi, A., Herry., Setyorini, A. Surahman dan E. Ridwan. (2007). Pemanfaatan Limbah Sawit untuk Pakan Ikan. Jurnal Budidaya Air Tawar, 4(1):11-18.

Khan, M.S, Ang, K.J, Ambak, M.A, Saad, C.R. (1993). Optimum Dietary Protein Requirement of a Malaysian Freshwater
Catfish, Mystus nemurus. Aquaculture, 112:227-235.

Kurniasih, T., Indra, F., Irma, M., Zafril, I.A. (2012). Pemberian ekstrak enzim kasar dari cairan rumen domba pada tepung bungkil kedelai lokal dan pengaruhnya terhadap pertumbuhan ikan nila. Jurnal Riset perikanan Akuakultur , 7 (2): 247:356 hlm.

Lamid, M., Nugroho, T.P., Chusniati, S., Rochima, K. (2011). Exploration celluloytic of bacterium of rumen liquid beef cattle as inoculums of waste agriculture. Veterinaria Medika, 4(1): 37-42.

Lesmana, D.S. (2001). Budidaya Ikan Hias Air Tawar Populer. Penebar Swadaya. Jakarta.

Muskita, W.H. (2012). Subsitusi Tepung Bungkil Kedele, Glycine max, dengan tepung bungkil biji kapuk, Ceiba petandra, dalam Pakan Juvenil Udang Vaname Litopenaeus vannamei : Kajian histologi, enzimatik dan komposisi asam lemak. Disertasi. Bogor (ID): Institut Pertanian Bogor.

Rahmad, F.A. (2017). Pemanfaatan tepung eceng gondok (Eichhornia crassipes) terfermentasi menggunakan cairan rumen sapi dalam pakan terhadap pertumbuhan benih ikan jelawat (Leptobarbus hoeveni). Skripsi. Fakultas Perikanan dan Kelautan. Universitas Riau. Pekanbaru. $15 \mathrm{hlm}$.

Suprayudi, M.A. (2010). Bahan Baku Lokal: Tantangan dan Harapan Akuakultur Indonesia. Prosiding Simposium Nasional Bioteknologi Akuakultur III 2010. Bogor. \& Oktober 2010, 31 pp.

Suwarsito dan Anggoro, S. (2005). Pemanfaatan Ampas Tahu dengan Metode Fermentasi untuk Bahan Baku Ikan Lele. Laporan Penelitian. Universitas Muhammadiyah Purwokerto. Purwokerto.

Sibarani, D.YR. (2018). Pemanfaatan Tepung Daun Eceng Gondok (Eichhornia Crassipes) Terfermentasi Menggunakan Cairan Rumen Sapi dalam Pakan Terhadap Pertumbuhan Benih Ikan Patin Siam (Pangasius hypophthalmus). Journal Online Mahasiswa. 
Syafriadiman, et al. (2005). Prinsip Dasar Pengolahan Kualitas Air. Mina Mandiri Press. Pekanbaru. $131 \mathrm{hlm}$.

Syarifah, H. (2014). Potensi Penggunaan Tepung Eceng Gondok (Eichhornia crassipes) Terfermentasi dalam Pakan Terhadap Pertumbuhan Benih Ikan Baung (Mystus nemurus CV). Fakultas Perikanan dan Ilmu Kelautan. Universitas Riau. Pekanbaru. $16 \mathrm{hlm}$.

Ugwuanyi, J.B.O, Mcneil and L.M. Hervet, L. 2009. Nutrition and Marculture. The John Hopkins University Press. 12-32 hlm.
Watanabe, T. 1988. Fish Nutrition and Mariculture. Department of Aquatic Biosciencis Fisheries. University of Tokyo. 233 pp.

Wuryantoro, S. (2000). Kandungan Protein Kasar dan Serat Kasar Hay Padi Teramonisasi yang Difermentasi dengan Cairan Rumen. Fakultas Kedokteran Hewan. Universitas Airlangga. Surabaya, $47 \mathrm{hlm}$. 